\title{
DAMPAK KEMAMPUAN KERJA MENINGKATKAN MOTIVASI KERJA IMPLIKASINYA PADA PRODUKTIVITAS KERJA KARYAWAN PT PINDAD BANDUNG
}

\author{
Ahmad Kahfi Sobar \\ Universitas Pendidikan Indonesia \\ ahmad.kahfi@student.upi.edu \\ Syamsul Hadi Senen \\ Universitas Pendidikan Indonesia \\ Syamsulhadisenen@upi.edu \\ Eded Tarmendi \\ Universitas Pendidikan Indonesia \\ ededtarmendi@upi.edu
}

\begin{abstract}
ABSTRAK
Tujuan- Seberapa besar pengaruh kemampuan kerja terhadap motivasi kerja, motivasi kerja terhadap produktivitas kerja dan kemampuan kerja terhadap produktivitas kerja karyawan

Desain/metodologi/Pendekatan- Jenis penelitian yang digunakan adalah deskriptif, verifikatif, dengan jumlah sampel sebanyak 57 karyawan. Teknik analisa data yang digunakan adalah regresi linear sederhana. Temuan- Dari penelitian terhadap pengujian hipotesis dapat diketahui bahwa kemampuan kerja memiliki pengaruh yang positif/kategori besar, baik terhadap motivasi kerja maupun produktivitas kerja karyawan.

Orisinalitas- Perbedaan ditemukan dalam objek penelitian, periode penelitian, alat ukur dan hasil penelitian. Penulis juga menambahkan teori dari jurnal asing dan buku asing
\end{abstract}

Kata kunci: kemampuan kerja,motivasi kerja, produktivitas kerja karyawan, manajemen sumber daya manusia

Tipe artikel: penelitian

\section{PENDAHULUAN}

Rendahnya produktivitas tenaga kerja menjadi issue utama pada bidang manajemen sumber daya manusia. Produktivitas kerja karyawan merupakan suatu kaitan antara input dan output berupa hasil kerja dengan waktu yang dibutuhkan sehingga menghasilkan produk oleh karyawan (Sutrisno, 2011). Produktivitas kerja karyawan yang efektif dan efisien sangat penting bagi perusahaan guna untuk pencapaian tujuan yang sudah ditetapkan perusahaan. Peningkatan kualitas dan produktivitas tenaga kerja adalah kata kunci untuk dapat mengejar ketertinggalan sehingga memaksimalkan produktivitas kerja karyawan menjadi tantangan bagi setiap perusahaan (Bernardin, H, John. Russel, 2007), (Anyadike \& O, 2013).

Masalah produktivitas kerja karyawan diberbagai negara khususnya menyoroti industri peralatan militer menunjukkan permasalah yang sama bahwa karyawan adalah asset penting bagi perusahaan. Harus selalu memperhatikan dan menjaga produktivitas kerja para karyawan karena jika produktivitas tenaga kerjanya rendah maka akan menimbulkan masalah yang berpengaruh terhadap peningkatan ekonomi dan daya saing global (Prescott, Daza, \& Mead, 2013), (Ismail \& Rosa, 2012)

Produktivitas adalah hal yang sangat penting dalam perusahaan, (Sutrisno, 2011) Produktivitas tenaga kerja tidak berdiri sendiri, dipengaruhi oleh beberapa faktor-faktor yang menyebabkan produktivitas karyawan belum optimal. Hal ini sesuai dengan pernyataan yang diungkapkan menurut (Sutermeitser, 1976) terdapat 32 faktor yang mempengaruhi produktivitas yang paling dominan diantaranya: kemampuan (ability) dan motivasi (motivation). Faktor-faktor yang mempengaruhi produktivitas, yaitu: knowledge (pengetahuan), skills (keahlian), abilities (kemampuan), attitudes (sikap), dan behaviours (tingkah laku), (Gomez-Mejia, 2012) (Dinesh, 2010). Berbeda dengan hal tersebut penelitian yang dilakukan oleh (Ali, Syed, Anka, Jamali, \& Shaikh, 2017) menyebutkan bahwa faktor-faktor produktivitas salah satunya yaitu mengenai motivasi. Membuat seorang karyawan bereaksi sesuai dengan keinginan organisasi untuk meningkatkan produktivitas. Sehingga dapat mencapai tujuan organisasi yang diinginkan. 
Motivasi bukan hanya satu-satunya faktor yang mempengaruhi produktivitas kerja seseorang. Dua faktor lainnya yang terlibat adalah kemampuan individu dan pemahaman tentang perilaku yang diperlukan untuk mencapai produktivitas kerja yang tinggi disebut persepsi peranan (Senen, Hadi Syamsul dan Solihat, 2013).

Berdasarkan analisis kondisi di atas, maka faktor yang menjadi penyebab rendahnya produktivitas karyawan suatu perusahaan yaitu kemampuan kerja yang berpengaruh juga pada motivasi kerja, maka hal tersebut harus ditingkatkan. Apabila masalah-masalah tersebut dibiarkan maka akan mengancam keberlangsungan aktivitas perusahaan. Sehingga dibutuhkan solusi yang tepat untuk mengatasi permasalahan tersebut.

Adapun tujuan penelitian ini adalah: (1) mendeskripsikan kemampuan kerja, (2) mendeskripsikan motivasi kerja karyawan, (3) mendeskripsikan produktivitas kerja karyawan, (4) seberapa besar pengaruh kemampuan kerja terhadap motivasi kerja karyawan, (5) seberapa besar pengaruh motivasi kerja karyawan terhadap produktivitas kerja karyawan.

\section{KAJIAN PUSTAKA}

Kemampuan kerja dapat diartikan sebagai kesanggupan, kecakapan, dan kekuatan kita berusaha dengan diri sendiri (Milman yusdi, 2010). Keseimbangan antara kerja dan sumber daya pribadi harus diperhatikan oleh karyawan (Harma, 2011). Serta suatu kapasitas yang dibutuhkan seseorang dalam melakukan tugas, hasil diperoleh dari latihan serta pengalaman sebagai implikasi dari aktivitas yang dilakukan dan berhubungan dengan orang lain (Mulyadi, 2016). Sedangkan dalam penelitian ini dimensi yang digunakan untuk mengukur kemampuan kerja adalah, menurut (Sutermeitser, 1976) yaitu pengetahuan (knowledge) dan keterampilan (skill).

$$
\begin{aligned}
& \text { Job Knowledge merupakan seberapa } \\
& \text { luasnya pengetahuan pegawai mengenai } \\
& \text { pekerjaan dan keterampilan. Indikator yang } \\
& \text { berhubungan dengan luasnya pengetahuan } \\
& \text { mengenai pekerjaan dan keterampilan yang } \\
& \text { dimiliki karyawan dan kemampuan karyawan } \\
& \text { untuk terus mengembangkan diri dengan } \\
& \text { pengetahuan yang lebih baik (Masharyono, n.d.). } \\
& \text { Motivasi merupakan keinginan dan } \\
& \text { dorongan yang timbul dari diri setiap individu } \\
& \text { untuk bekerja dengan cara tertentu untuk } \\
& \text { mencapai tujuan secara optimal (Gomez-Mejia, } \\
& \text { 2012) (Novianti \& Senen, 2016). Sedangkan } \\
& \text { dimensi untuk mengukur motivasi kerja dalam } \\
& \text { penelitian ini yaitu: 1. kebutuhan fisiologis } \\
& \text { (physilogical needs), 2. kebutuhan keselamatan }
\end{aligned}
$$

dan keamanan (safety and security needs), 3. kebutuhan sosial (social needs), 4. kebutuhan akan penghargaan (ego or self asteem needs), 5 . kebutuhan aktualisasi diri (self actualization needs) menurut (Wahjono, 2010).

Motivasi pada manusia merupakan unsur yang sangat penting karena sebagai pendorong untuk melakukan sesuatu. Oleh karena itu, perusahaan yang ingin mencapai tujuannya harus memberikan perhatian berupa pemberian motivasi kerja pada karyawannya. Dengan kata lain, motivasi kerja adalah keseluruhan proses pemberian motivasi bekerja kepada bawahan sedemikian rupa sehingga mereka mau bekerja dengan ikhlas demi tercapainya tujuan organisasi dengan efisien dan ekonomis (Mulyadi, Hari dan Marliana, 2010)

Produktivitas dapat diartikan sebagai ukuran dari seberapa besar nilai individu karyawan menghasilkan barang atau jasa sebagai besaran produksi organisasi. Semakin besar output per individu, semakin tinggi produktivitas organisasi, (Gomez-Mejia, 2012). Sedangkan dalam penelitian ini dimensi yang digunakan untuk mengukur produktivitas kerja adalah, menurut (Stephen P. Robbins, Mary Coulter., 2012) produktivitas dapat terlihat jika seorang karyawan menggunakan seluruh kemampuannya dan kekuatannya serta disertai dengan pengerahan potensi dan kreatifitas dalam melaksanakan tugas kerjanya agar tujuan perusahaan yang ingin dicapai dapat tercapai secara efektif dan efisien.

Gambar 1 Paradigma Penelitian

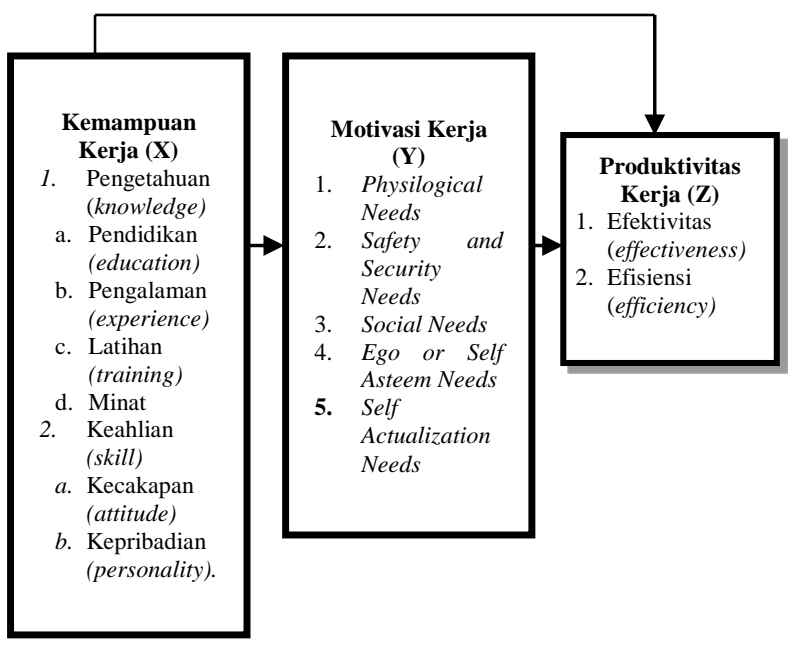

\section{METODE}

Penelitian ini menganalisis mengenai pengaruh kemampuan kerja terhadap motivasi kerja dan implikasinya pada produktivitas kerja karyawan PT PINDAD Divisi Tempa dan Cor (TC) Bandung. Dalam penelitian ini yaitu kemampuan kerja dimensinya terdiri dari pengetahuan (knowledge), dan keterampilan 
(skill). Dalam penelitian ini, Motivasi kerja sebagai variabel (intervening) yang kedua terdiri dari 1) kebutuhan fisiologis (physilogical needs); 2) kebutuhan keselamatan dan keamanan (safety and security needs); 3) kebutuhan sosial (social needs); 4) kebutuhan akan penghargaan (ego or self asteem needs); 5) kebutuhan aktualisasi diri (self actualization needs). Sedangkan yang menjadi variabel terikat atau dependent variabel adalah produktivitas kerja dengan dimensinya yang mencakup efisiensi dan efektifitas.

Penelitian ini dilakukan di PT PINDAD pada karyawan divisi Tempa dan Cor (TC). Berdasarkan kurun waktu penelitian yang dilaksanakan pada kurun waktu kurang dari satu tahun, maka metode penelitian yang digunakan adalah cross sectional method. Teknik sampel yang digunakan dalam penelitian ini adalah teknik simple random sampling dengan mengambil sebanyak 57 karyawan pada Divisi Tempa dan Cor (TC) PT PINDAD Bandung. Teknik pengumpulan data yang digunakan adalah studi literatur, observasi, wawancara dan kuesioner. Sedangkan teknik analisis data yang dilakukan adalah analisis deskriptif dan verifikatif

\section{HASIL PENELITIAN DAN PEMBAHASAN Pengaruh Kemampuan terhadap Motivasi Motivasi =13,709+ 0,692 Kemampuan}

Berdasarkan persamaan regresi linear sederhana, konstanta sebesar 13,709 menyatakan bahwa jika tidak ada kemampuan kerja, maka besarnya motivasi kerja sebesar 13,709. Koefesien regresi sebesar 0,692 satu satuan nilai artinya setiap terjadi peningkatan kemampuan kerja akan meningkatkan motivasi kerja karyawan sebesar 0,692 satu satuan nilai dan sebaliknya jika terjadi penurunan pada kemampuan kerja, maka akan menurunkan motivasi kerja sebesar 0,692 satu satuan nilai.

Korelasi antara kemampuan kerja terhadap motivasi kerja adalah sebesar 0,647 karena berada pada interprestasi koefisien korelasi $(0,60-0,799)$ artinya terdapat hubungan yang kuat antara kemampuan kerja terhadap motivasi kerja. Nilai p-value pada kolom sig. (2-tailed) $0.000<0,05$ level of significant $(\alpha)$, artinya kemampuan kerja berkorelasi dengan motivasi kerja.

Untuk mengetahui besarnya pengaruh variabel kemampuan kerja terhadap variabel motivasi kerja. menunjukkan adanya nilai RSquare sebesar 0,419 atau $41,9 \%$. Hal ini menunjukkan bahwa besarnya kontribusi variabel kemampuan kerja terhadap motivasi kerja sebesar $41,9 \%$, artinya $41,9 \%$ motivasi kerja dipengaruhi oleh kemampuan kerja dan sisanya yaitu sebesar $58.1 \%$ dipengaruhi oleh faktor lain yang tidak diteliti.
Uji hipotesis dalam penelitian ini adalah dengan menggunakan uji t ( $t$-Test), diperoleh nilai $t_{\text {hitung }}$ sebesar 6,294 dengan tingkat signifikansi $5 \%$. Dibandingkan dengan nilai $t_{\text {tabel }}$, perolehan nilai $t_{\text {hitung }}$ memiliki angka yang lebih besar daripada nilai $t_{\text {tabel }}(6,294>1,67303)$, maka dapat diambil keputusan bahwa hipotesis nol $\left(\mathrm{H}_{0}\right)$ ditolak dan $\mathrm{H}_{\mathrm{a}}$ diterima. Artinya bahwa terdapat pengaruh positif kemampuan kerja terhadap motivasi kerja PT PINDAD Bandung.

Hal ini berarti antara kemampuan kerja memiliki hubungan signifikan/positif terhadap motivasi kerja. Hal tersebut sesuai dengan penelitian yang dilakukan oleh penelitian (Salleh, 2011) pemberian motivasi kepada karyawan berhubungan secara signifikan terhadap kemampuan kerja karyawa. Sedangkan menurut Moorhead dan Griffin (1998) dalam (Iqbal, Yusaf, Munawar, \& Naheed, 2012) Employee motivation and ability jointly contribute towards employee performance and the most challenging task of the managers is to motivate employee to execute the utmost of their ability. Artinya motivasi dan kemampuan karyawan bersamasama berkontribusi terhadap produktivitas karyawan dan tugas yang paling menantang dari manajer adalah untuk memotivasi karyawan untuk melaksanakan sepenuhnya kemampuan mereka.

Berdasarkan penjelasan yang telah disebutkan sebelumnya, dapat diketahui bahwa kemampuan dan motivasi kerja memiliki keterkaitan. Motivasi seorang pekerja untuk bekerja biasanya merupakan hal yang rumit, karena motivasi itu melibatkan faktor-faktor individual dan faktor organisasional, (faustio gomez, 2003). Tergolong pada faktor-faktor yang sifatnya individual adalah kebutuhan-kebutuhan (needs), tujuan-tujuan (goals), sikap (attitudes), dan kemampuan-kemampuan (abilities). Sedangkan yang tergolong pada faktor-faktor yang berasal dari organisasi meliputi pembayaran atau gaji (pay), pengawasan (supervision), pujian (praise) dan pekerjaan itu sendiri (job it self). dalam hal ini kemampuan (abilitties) merupakan salah satu faktor yang mempengaruhi motivasi kerja.

\section{Pengaruh Motivasi terhadap Produktivitas Produktivitas $=6,425+0,480$ Motivasi}

Berdasarkan persamaan regresi linear sederhana, konstanta sebesar 6,425 menyatakan bahwa jika tidak ada motivasi kerja, maka besarnya produktivitas kerja sebesar 6,425. Koefesien regresi sebesar 0,480 satu satuan nilai artinya setiap terjadi peningkatan motivasi kerja akan meningkatkan produktivitas kerja karyawan sebesar 0,480 satu satuan nilai dan sebaliknya jika terjadi penurunan pada motivasi kerja, maka akan 
menurunkan produktivitas kerja sebesar 0,480 satu satuan nilai.

Analisis koefisien korelasi ini untuk menguji ada tidaknya korelasi atau hubungan dari variabel independen terhadap variabel dependen. Berdasarkan pada hasil pengolahan data yang dilakukan, nilai yang diperoleh menjelaskan bahwa korelasi antara motivasi kerja terhadap produktivitas kerja karyawan adalah sebesar 0,687 karena berada pada interprestasi koefisien korelasi $(0,60-0,799)$ artinya terdapat hubungan yang kuat antara motivasi kerja terhadap produktivitas kerja. Nilai p-value pada kolom sig. (2-tailed) $0.000<0,05$ level of significant $(\alpha)$, artinya motivasi kerja berkorelasi dengan produktivitas kerja.

Untuk mengetahui besarnya pengaruh variabel motivasi kerja terhadap variabel produktivitas kerja, maka digunakan rumus koefesien determinasi. Nilai R-Square sebesar 0,472 atau $47,2 \%$. Hal ini menunjukkan bahwa besarnya kontribusi variabel motivasi kerja terhadap produktivitas kerja sebesar 47,2\%, artinya $47,2 \%$ produktivitas kerja dipengaruhi oleh motivasi kerja dan sisanya yaitu sebesar $52.8 \%$ dipengaruhi oleh faktor lain yang tidak diteliti.

Uji hipotesis dalam penelitian ini adalah dengan menggunakan uji t ( $t$-Test) diperoleh nilai $\mathrm{t}_{\text {hitung }}$ sebesar 7,012 dengan tingkat signifikansi 5\%. Dibandingkan dengan nilai $t_{\text {tabel}}$, perolehan

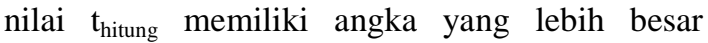
daripada nilai $\mathrm{t}_{\text {tabel }}(7,012>1,67303)$, maka dapat diambil keputusan bahwa hipotesis nol $\left(\mathrm{H}_{0}\right)$ ditolak dan $\mathrm{H}_{\mathrm{a}}$ diterima. Artinya bahwa terdapat pengaruh positif motivasi kerja terhadap produktivitas kerja PT PINDAD Bandung.

Hal ini berarti antara motivasi kerja dengan produktivitas kerja memiliki hubungan signifikan/positif. Sehingga, semakin baik motivasi kerja maka akan semakin tinggi pula produktivitas kerja karyawan. Hal tersebut sesuai dengan penelitian yang dilakukan oleh penelitian Samrya (2012) bahwa pemberian motivasi kepada karyawan berhubungan secara signifikan terhadap produktivitas kerja karyawan. Pendapat serupa ditemukan dalam penelitian menurut Moorhead dan Griffin (1998) dalam (Iqbal et al., 2012) Employee motivation and ability jointly contribute towards employee performance and the most challenging task of the managers is to motivate employee to execute the utmost of their ability. Artinya motivasi karyawan bersama-sama berkontribusi terhadap produktivitas karyawan.

Demikian juga menurut Gaspersz dalam (Yuniarsih, Tjutju, 2009) faktor-faktor yang mempengaruhi produktivitas kerja seorang karyawan dalam sebuah perusahaan adalah seleksi karyawan, pelatihan kerja, lingkungan kerja, hubungan antara pimpinan dan bawahan, sistem penggajian dan motivasi. Motivasi akan meningkatkan tingkat kebahagiaan di tempat kerja. Tenaga kerja yang termotivasi akan berkomitmen untuk kinerja kualitas tinggi. meningkatkan kualitas kehidupan kerja akan membantu karyawan untuk meningkatkan produktivitas (Owusu, 2012).

Tinggi rendahnya kinerja dan produktivitas para pegawai dapat dipengaruhi beberapa faktor, (Sinungan, 2008) antara lain: kemampuan dan kemauan kerja, fasilitas kerja yang digunakan, disamping itu juga tepat atau tidaknya cara yang dipilih perusahaan/instansi dalam memberikan motivasi kepada pegawai, dengan cara yang tepat dalam memotivasi pegawai untuk bekerja, semakin terlihat peningkatan produktivitas sesuai yang diharapkan oleh perusahaan. Pemberian motivasi yang lebih kepada karyawan untuk bekerja secara maksimal akan mendorong produktivitas kerja secara keseluruhan dan memberikan feedback yang tepat terhadap perusahaan, sehingga dapat meningkatkan produktivitas perusahaan tersebut. Jadi dapat dikatakan bahwa keberhasilan suatu organisasi sangat didukung dari tingkat produktivitas kerja yang dihasilkan.

\section{Pengaruh Motivasi terhadap Produktivitas Produktivitas $=5,611+0,588$ Kemampuan}

Berdasarkan persamaan regresi linear sederhana, konstanta sebesar 5,611 menyatakan bahwa jika tidak ada kemampuan kerja, maka besarnya produktivitas kerja sebesar 5,611. Koefesien regresi sebesar 0,588 satu satuan nilai artinya setiap terjadi peningkatan kemampuan kerja akan meningkatkan produktivitas kerja karyawan sebesar 0,588 satu satuan nilai dan sebaliknya jika terjadi penurunan pada kemampuan kerja, maka akan menurunkan produktivitas kerja sebesar 0,588 satu satuan nilai.

Analisis koefisien korelasi ini untuk menguji ada tidaknya korelasi atau hubungan dari variabel independen terhadap variabel dependen. Korelasi antara kemampuan kerja terhadap produktivitas kerja karyawan adalah sebesar 0,788 karena berada pada interprestasi koefisien korelasi $(0,60-0,799)$ artinya terdapat hubungan yang kuat antara kemampuan kerja terhadap produktivitas kerja. Nilai p-value pada kolom sig. (2-tailed) $0.000<0,05$ level of significant $(\alpha)$, artinya kemampuan kerja berkorelasi dengan produktivitas kerja.

Untuk mengetahui besarnya pengaruh variabel kemampuan kerja terhadap variabel produktivitas kerja, maka digunakan rumus koefesien determinasi. Nilai R-Square sebesar 0,621 atau $62,1 \%$. Hal ini menunjukkan bahwa 
besarnya kontribusi variabel kemampuan kerja terhadap produktivitas kerja sebesar 62,1\%, artinya $62,1 \%$ produktivitas kerja dipengaruhi oleh kemampuan kerja dan sisanya yaitu sebesar $37.9 \%$ dipengaruhi oleh faktor lain yang tidak diteliti.

Perhitungan uji-t diperoleh nilai $t_{\text {hitung }}$ sebesar 9,485 dengan tingkat signifikansi $5 \%$. Dibandingkan dengan nilai $t_{\text {tabel}}$, perolehan nilai $\mathrm{t}_{\text {hitung }}$ memiliki angka yang lebih besar daripada nilai $t_{\text {tabel }}(9,485>1,67303)$, maka dapat diambil keputusan bahwa hipotesis nol $\left(\mathrm{H}_{0}\right)$ ditolak dan $\mathrm{H}_{\mathrm{a}}$ diterima. Artinya bahwa terdapat pengaruh positif kemampuan kerja terhadap produktivitas kerja PT PINDAD Bandung.

Hal ini berarti antara kemampuan kerja dengan produktivitas kerja memiliki hubungan signifikan/positif. Sehingga, semakin baik kemampuan kerja maka akan semakin tinggi pula produktivitas kerja karyawan. Hal tersebut sesuai dengan penelitian yang dilakukan oleh penelitian (Mangkunegara, 2011) yang menyatakan bahwa tercapainya produktivitas kerja karyawan akan sangat ditentukan oleh kemampuan yang dimiliki karyawan itu sendiri. Bagi karyawan yang memiliki kemampuan diatas rata-rata dengan kemampuan yang memadai dengan jabatanya, dan memiliki keterampilan dalam melakukan tugas sehari-hari, maka akan mampu mencapai tingkat produktivitas kerja yang tinggi.

(Faustio Gomez, 2003) menyebutkan faktorfaktor yang mempengaruhi produktivitas adalah knowledge (pengetahuan), skills (keahlian), abilities (kemampuan), attitudes (sikap), dan behaviours (tingkah laku). Pendapat yang sama juga dikemukakan oleh (Sutermeitser, 1976) terdapat 32 faktor yang mempengaruhi produktivitas, salah satunya yaitu kemampuan. hal ini menunjukkan bahwa kemampuan dan produktivitas saling mempengaruhi.

Suatu perusahaan akan dikatakan berhasil jika perusahaan itu sudah mencapai tujuan yang telah ditetapkan sebelumnya. Keberhasilan perusahaan mencapai tujuannya tidak terlepas dari produktivitas individu karyawannya. Karyawan adalah asset utama perusahaan dan menjadi ujung tombak perusahaan untuk mencapai tujuan perusahaan. Hal ini sejalan dengan teori menurut (Sulistiyani, 2009) berpendapat bahwa pengetahuan dan keterampilan sesungguhnya yang mendasari pencapaian produktivitas.

\section{KESIMPULAN DAN REKOMENDASI}

Berdasarkan hasil penelitian yang telah dilakukan menggunakan analisis deskriptif dan verifikatif dengan menggunakan teknik analisis regresi linear sederhana dapat diambil kesimpulan sebagai berikut. Hasil penelitian menyatakan bahwa kemampuan kerja berpengaruh positif terhadap motivasi kerja, motivasi kerja berpengaruh positif terhadap produktivitas kerja karyawan dan kemampuan kerja berpengaruh positif terhadap produktivitas kerja karyawan.

Penelitian ini diharapkan dapat membantu kepada peneliti berikutnya dalam melakukan penelitian mengenai kemampuan kerja, motivasi kerja dan produktivitas kerja karyawan dengan indikator serta objek yang berbeda dan adanya tambahan pada teori-teori yang digunakan. Karena masih banyaknya keterbatasan didalam penelitian ini, khususnya kelemahan yang berkaitan dengan metode penelitian, teknik pengumpulan data dan sampel yang terlibat.

\section{DAFTAR PUSTAKA}

Ali, A., Syed, S. G., Anka, L. M., Jamali, M. B., \& Shaikh, F. M. (2017). Motivation as a Tool for Effective Staff Productivity in the Public Sector: A Case Study of Raw Materials Research and Development Council of Nigeria, 8(11). http://doi.org/10.5539/ass.v8n11p85

Anyadike, \& O, N. (2013). Human Resource Planning and Employee Productivity in Nigeria. Global Journal of Human Resource Management, 1(December), 5668.

Bernardin, H, John. Russel, J. E. . (2007). Human Resource Management: an Experimental Approach. singapore: McGraw-Hill Book co.

Dinesh, G. P. (2010). Asian journal of management research, 147-152.

faustio gomez. (2003). Manajemen Sumber Daya Manusia. Yogyakarta: Andi Offset.

Gomez-Mejia, L. R. et. a. (2012). Managing Human Resources. USA: Pearson Education, Inc., publishing as Prentice Hall.

Harma, M. (2011). Are long workhours a health risk, 29(3), 167-169. http://doi.org/10.5271/sjweh.719

Iqbal, J., Yusaf, A., Munawar, R., \& Naheed, S. (2012). I Nterdisciplinary J Ournal O F C Ontemporary R Esearch I N B Usiness Employee Motivation In Modern Organization, 4 No 3, 692-708.

Ismail, P. R., \& Rosa, A. (2012). Review of Economics \& Finance Globalisation and Labour Productivity in the Malaysian Manufacturing Sector, (1997), 117-118.

Mangkunegara, P. A. (2011). Manajemen Sumber Daya Manusia Perusahaan. Bandung: PT. Remaja Rosdakarya Bandung.

Masharyono. (n.d.). Characteristics Dalam Mendukung Universitas Pendidikan Indonesia Mencapai Leading And Outstanding, 120-137. 
Milman yusdi. (2010). Belajar dan Pembelajaran. Jakarta: Rineka Cipta.

Mulyadi, Hari dan Marliana, N. (2010). Kinerja Karyawan Pada Departemen Weaving, Volume 9, .

Mulyadi, H. (2016). Pengaruh Keterampilan Wurausaha terhadap Keberhasilan Usaha, 1(1), 213-223.

Novianti, N., \& Senen, S. H. (2016). Pengaruh Lingkungan Kerja Sosial, Keselamatan dan Kesehatan Kerja terhadap Kepuasan Kerja Karyawan PT Karya Yusup di Bandung, $1(1)$.

Owusu, T. (2012). Effects Of Motivation On Employee Performance. Institute of Distance Learning, KNUST.

Prescott, E. C., Daza, R., \& Mead, H. (2013). Ideological Profiles of the Economics, 10(September), 556-559.

Salleh, F. (2011). The Effect of Motivation on Job Performance of State Government Employees in, 1(4), 147-154.

Senen, Hadi Syamsul dan Solihat, S. (2013). Pengaruh Motivasi dan Kemampuan Kerja Terhadap Produktivitas Kerja Karyawan Pada, 7(September), 1-15.

Sinungan, M. (2008). Produktivitas Apa dan Bagaimana. Jakarta: Bumi Aksara.

Stephen P. Robbins, Mary Coulter., -. (2012). Management. Jakarta: England.

Sulistiyani, A. T. (2009). Manajemen Sumber Daya Manusia. Jogyakarta: Graha Ilmu.

Sutermeitser. (1976). People And Productivity (3rd ed.). USA: MC.

Sutrisno, E. (2011). Budaya Organisasi. Jakarta: Prenada Media Group.

Wahjono, S. I. (2010). Perilaku Organisasi. Yogyakarta: Graha Ilmu.

Yuniarsih, Tjutju, \& S. (2009). Manajemen Sumber Daya Manusia. Bandung: Alfabeta. 